\title{
ANALISA DELAY YANG TERJADI PADA PENERAPAN DEMILITARIZED ZONE (DMZ) TERHADAP SERVER UNIVERSITAS ANDALAS
}

\author{
Syariful Ikhwan dan Ikhwana Elfitri \\ Teknik Elektro, Fakultas Teknik Universitas Andalas
}

\begin{abstract}
Abstrak-Keamanan jaringan sangat vital bagi sebuah jaringan komputer. Kelemahan-kelemahan yang terdapat pada jaringan komputer jika tidak dilindungi dan dijaga dengan baik akan menyebabkan kerugian berupa kehilangan data, kerusakan sistem server, tidak maksimal dalam melayani user atau bahkan kehilangan aset-aset berharga institusi. Dalam menjaga keamanan jaringan komputer dan server maka dikembangkanlah berbagai metoda perlindungan diantaranya firewall DMZ (Demiliterized Zone). DMZ adalah sebuah metoda firewall yang melakukan pengelompokan terhadap server-server sehingga lalu lintas data yang lewat bisa diatur dengan lebih baik. Hasil penelitian terhadap penerapan metoda DMZ di Universitas Andalas mengurangi secara signifikan serangan terhadap sistem server yang ada. Penerapan metoda DMZ di Universitas Andalas menunjukkan terjadinya delay terhadap paket yang keluar masuk sebesar $0,1544 \mathrm{~ms}$. Persentase delay ini naik sebesar $126 \%$ dari delay sebelumnya.
\end{abstract}

Kata Kunci: Keamanan Jaringan, Enkripsi, Server, Delay, DMZ

\begin{abstract}
Network security is vital to a computer network. Weaknesses in computer networks if not maintained and protected will cause harm in the form of data loss, damage of system server, not optimal in serving the user or even the loss of valuable institutional assets. To maintaining the security of computer networks and servers, various methods were developed, including firewall DMZ (Demiliterized Zone). DMZ is a firewall method of grouping the servers so that the data traffic passing could be better regulated. The results of a study of the application of the method at the University of Andalas DMZ significantly reduce attacks on existing server systems. Application of the method of the DMZ at Andalas University shows the packet delay to the entry and exit of $0.1544 \mathrm{~ms}$. This delay percentage increased by $126 \%$ from the previous delay.
\end{abstract}

Keywords: Network Security,Encryption, Server, Delay, DMZ

\section{PENDAHULUAN}

Universitas Andalas (UNAND) adalah perguruan tinggi tertua di luar Pulau Jawa, dan menjadi universitas tertua ke-empat di Indonesia. UNAND didirikan pada tahun 1956 melalui SK Menteri Pendidikan dan Kebudayaan No.80016/Kab/23 Desember 1955. Saat ini menjelang usia 58 tahun, Universitas Andalas telah berkembang demikian pesat dan mulai meningkatkan peralihan teknologi dari manual menjadi digital. Seiring perkembangan teknologi digital itu sendiri, maka akan banyak rintangan dan permasalahan yang akan dihadapi. Salah satu kendala yang akan dihadapi adalah dibidang teknologi informasi. Satu diantara tantangan itu adalah sistem keamanan. Sistem keamanan sistem informasi bisa jadi secara fisik maupun secara non fisik.

Secara fisik adalah keamanan server beserta perangkat pendukungnya dari pencurian, bencana alam dan kerusakan akibat kesalahan manusia. Sedangkan secara non fisik adalah berupa kerusakan sistem operasi server, kerusakan pada program aplikasi ataupun terhadap gangguan dari luar sistem seperti serangan hacker, virus, trojan dan lain sebagainya.

Administrator web seringkali mengabaikan aspek-aspek keamanan yang secara umum telah diketahui memiliki celah-celah untuk disusupi. Diantara kelalaian yang terjadi adalah seorang administrator web kurang memperhitungkan efek samping terhadap aplikasi-aplikasi yang di install pada webserver 
yang dikelolanya. Pada prinsipnya sebagian besar aplikasi tersebut memang diperlukan untuk mempermudah pekerjaan, namun saat sebuah program aplikasi diinstall maka program tersebut akan membuka sebuah port atau beberapa port yang dibutuhkannya untuk berkomunikasi dengan dunia luar. Port yang terbuka tersebut kemudian menjadi jalan bagi program jahat untuk masuk dan menyusup ke dalam sistem komputer.

Sesuai dengan solusi umum yang ingin dicapai dari keamanan jaringan, maka Universitas Andalas sudah semestinya menerapkan sistem keamanan jaringan yang dirancang terstruktur dengan baik. Kondisi sistem yang aman tentunya akan membuat klien merasa nyaman untuk melakukan transaksi di internet tanpa merasa was-was. Kondisi yang aman dan terjamin bisa diwujudkan dengan merancang sistem keamanan jaringan Universitas Andalas, salah satunya dengan menerapkan metoda Firewall menggunakan DMZ (Demiliterized Zone). Namun dalam penerapan DMZ, ada parameter yang menunjukkan nilai baik tapi juga memiliki dampak terhadap parameter lainnya seperti delay paket.

\section{TINJAUAN PUSTAKA}

\section{II.1 Keamanan Jaringan}

Internet dan World Wide Web (WWW) menjadi bagian yang penting bagi kehidupan banyak orang. Secara teratur, beragam transaksi terjadi melalui web yang melibatkan informasi pribadi ${ }^{[8]}$. Transaksi ini meliputi online banking, e-edukasi, e-commerce dan lain-lain. Setiap orang yang berkomunikasi meng-inginkan transaksi yang aman dan terjamin. Menurut Ammar Yassir dan Smitha Nayak, serangan terhadap mesin yang terhubung ke internet mengalami peningkatan $260 \%$ sejak tahun 1994 dan membuat kerugian sekitar 1.290 juta dollar setiap tahun di Amerika [12]. Oleh karena itu, keamanan jaringan menjadi signifikan bagi setiap pengguna internet ${ }^{[6]}$.

Keamanan jaringan pada intinya adalah mengendalikan akses terhadap sumberdaya jaringan. Akses jaringan dikontrol agar bisa diakses oleh siapa saja yang berhak dan menghalangi orang atau subjek yang tidak terdaftar untuk mengaksesnya.

Prinsip keamanan jaringan di klasifikasikan menjadi 3 bagian :

1. Confidentiality (Kerahasiaan)

Confidentiality mengacu pada kerahasiaan sebuah objek, dimana sebuah objek dijaga agar tidak diakses oleh subjek yang tidak berhak. Istilah ini juga mengacu pada data pribadi yang diberikan kepada pihak lain untuk keperluan tertentu dan hanya digunakan untuk keperluan tersebut. Contoh data-data yang sifatnya pribadi itu adalah nama, nomor kartu kredit, nomor paspor, nomor telepon, password komputer, agama, status perkawinan dan lain-lain ${ }^{[14]}$.

Ada banyak tool yang digunakan untuk menjaga agar kerahasiaan sebuah subjek terjaga dengan baik, diantaranya Enkripsi, Akses Kontrol, otentifikasi, otorisasi dan keamanan fisik.

\section{Integrity (Integritas)}

Integrity mengacu pada objek yang tetap asli (original), dimana objek tidak berubah di perjalanan hingga sampai ke tujuan dari objek tersebut. Sebagai contoh, email yang dikirim oleh seseorang bisa dicegat ditengah jalan kemudian diubah isinya dan selanjutnya baru dikirim ke penerima sebenarnya sehingga data yang diterima oleh penerima telah berubah dari yang diinginkan oleh pengirim. Bentuk serangan terhadap aspek integrity diantaranya adalah virus, trojan horse, atau pemakai lain yang berada ditengah komunikasi.

Untuk mengatasi hal tersebut, maka perlu dibuat mekanisme proteksi agar data tidak bisa diubah oleh pihak-pihak yang tak diizinkan. Tool yang digunakan untuk menjaga hal itu terlaksana diantaranya adalah Checksums, Data correcting codes dan backup.

\section{Availability ( Ketersediaan )}

Availability mengacu pada ketersediaan resource dengan tepat, dimana user mempunyai hak akses tepat waktu dan tidak terkendala apapun. 
Salah satu serangan terhadap aspek availability adalah serangan Distributed Denial of Service (DDoS Attack). Tujuan utama dari DDoS attack adalah memenuhi resource yang dibutuhkan oleh user sehingga user tidak bisa menggunakan resource tersebut sebagaimana harusnya. Selain DDoS attack, faktor lain yang mempengaruhi berkurangnya aspek availability adalah kelalaian manusia dan bencana alam. Tool yang digunakan untuk hal ini bisa jadi adalah perlindungan secara fisik dan penyimpanan redundan pada storage. Sedangkan untuk data-data yang sifatnya memiliki ketersediaan yang sangat penting, perlu adanya server cadangan yang senantiasa siap digunakan apabila server utama mengaami kerusakan.

\section{II.2 Demilitarized Zone (DMZ)}

Firewall DMZ atau jaringan perimeter adalah jaringan security boundary yang terletak diantara suatu jaringan privat LAN dan jaringan publik (internet).

DMZ didefinisikan sebagai sebuah host komputer atau jaringan kecil yang dimasukkan kedalam sebuah zona netral diantara sebuah jaringan perusahaan privat dan jaringan publik. DMZ menghalangi user dari luar mengakses secara langsung sebuah server yang berisi data-data perusahaan(Gambar 1) . Istilah ini berasal dari zona penyangga yang dibuat antara korea utara dan korea selatan mengikuti ketentuan PBB pada akhir tahun $1950^{[18]}$.

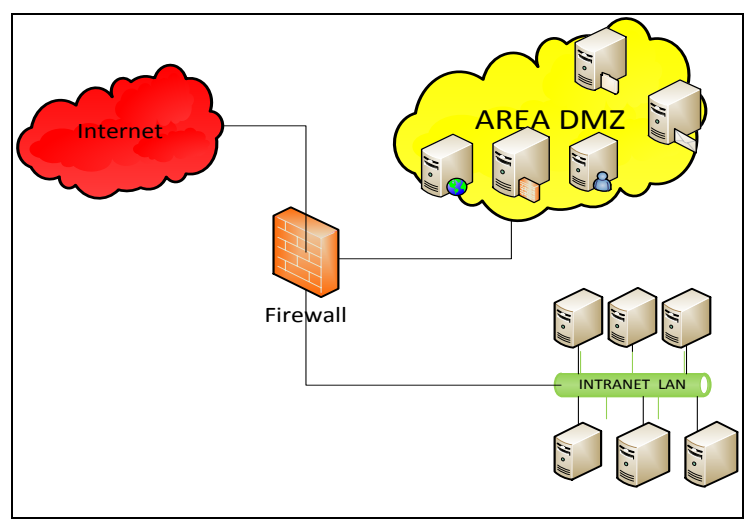

Gambar 1 Topologi DMZ

Konsep DMZ pada dasarnya mengaplikasikan konsep NAT (Network
Address Translation) dan PAT (Port Address Translation). NAT berfungsi mengarahkan alamat riil menjadi alamat internal sedangkan PAT berfungsi untuk mengarahkan data yang masuk melalui port atau sekumpulan port dan protokol ${ }^{[17],[18]}$.

Gambar 1 adalah ilustrasi pola aliran untuk lalu lintas data pada sebuah DMZ dasar. Trafik yang menuju DMZ bisa diizinkan atau ditolak, baik yang berasal dari internet ataupun jaringan internal. Lalu lintas data sepenuhnya diatur oleh firewall DMZ.

Umumnya, setiap layanan yang diberikan kepada pengguna di jaringan eksternal dapat ditempatkan dalam DMZ. Yang paling umum dari layanan ini adalah web server, mail server, ftp server, VoIP server dan DNS server.

\section{II.3 Penelitian yang berhubungan}

Berbagai penelitian yang berhubungan dengan DMZ telah dilakukan diantaranya oleh Glen Nakamoto dan kawan-kawan dengan melakukan perlindungan pada pengguna yang berada pada jaringan DMZ. Seluruh user yang melakukan transaksi data diperiksa oleh sebuah sistem DMZ yang menggabungkan kemampuan perangkat-perangkat tertentu yaitu Cisco dan Firewall Symantec [21]. Pada penelitian tersebut didapatkan kemampuan firewall DMZ yang mampu memeriksa paket yang lewat dari dan keluar jaringan DMZ. Namun jika diterapkan di jaringan Universitas Andalas, maka akan didapatkan kendala yang sangat banyak. Hal ini terjadi karena terdapat ribuan paket dalam satu waktu yang harus diperiksa sementara pada pengujian hanya dilakukan pada sedikit trafik.

Penelitian lain dilakukan oleh Anjali Sardana dan R.C. Josi [22] dengan menempatkan sebuah sistem pertahanan berupa honeypot untuk mengalihkan serangan terhadap server yang berada di jaringan DMZ. Metode ini cukup bagus, namun untuk kasus di Universitas Andalas terkendala dengan topologi jaringan yang masih belum tertata dengan rapi. 


\section{II.4 Delay}

Delay merupakan sebuah parameter yang cukup penting dalam merancang sebuah jaringan komputer. Delay adalah waktu tunda yang terjadi akibat proses transmisi dari satu titik ke titik lain. Delay pada jaringan TCP/IP terbagi dalam beberapa macam yaitu : Delay Antrian, Delay Propagasi, Delay Transmisi, dan Delay proses. Delay antrian diakibatkan oleh waktu tunggu paket hingga dilayani oleh router/host. Delay Propagasi diakibatkan oleh transmisi paket melalui jarak antara pengirim dan penerima. Skema delay pada jaringan bisa digambarkan sebagaimana pada gambar 2.

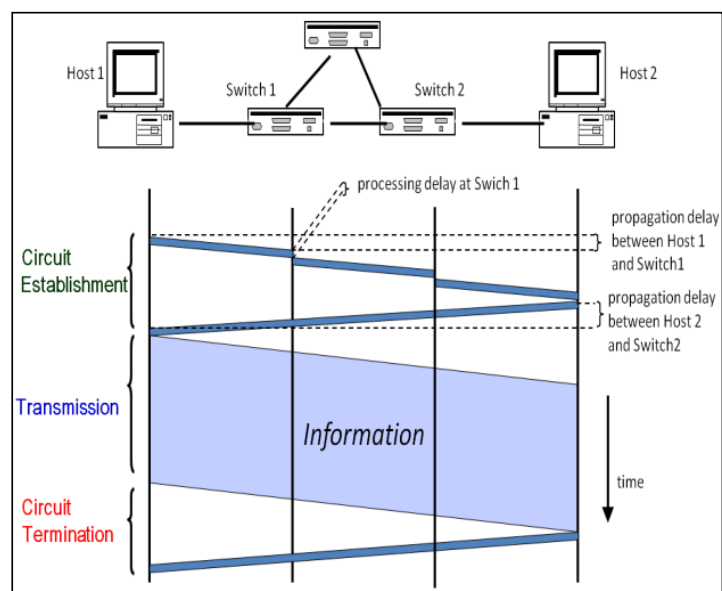

Gambar 2 Delay pada jaringan komputer (diambil dari presentasi kuliah Sistem Telekomunikasi)

Delay akan sangat berpengaruh pada jaringan yang menggunakan suara sebagai data yang akan ditransmisikan. Pada paket yang memuat informasi selain dari suara, delay masih bisa ditolerir walaupun cukup menggaggu. Besarnya delay maksimum yang direkomendasikan ITU untuk aplikasi suara adalah sebesar $150 \mathrm{~ms}$, sedangkan delay maksimum agar suara masih bisa diterima adalah sebesar $250 \mathrm{~ms}$.

Delay dapat dihitung dengan membagi panjang paket (L(bit/s)) dengan Link Bandwidth (R(bit/s)). Tool yang digunakan untuk menghitung nilai delay ini diantaranya adalah ping. Perintah ping akan menghasilkan nilai round-trip time (RTT). Round-trip delay adalah waktu yang dibutuhkan paket dari sumber ke tujuan dan kembali lagi ke sumber. Protokol yang digunakan adalah protokol Internet Control Message Protocol (ICMP)

\section{II.5 Kondisi awal Jaringan Universitas Andalas}

Gambaran umum kondisi jaringan Universitas Andalas saat belum diterapkan Firewall DMZ bisa dilihat dari gambar 3.

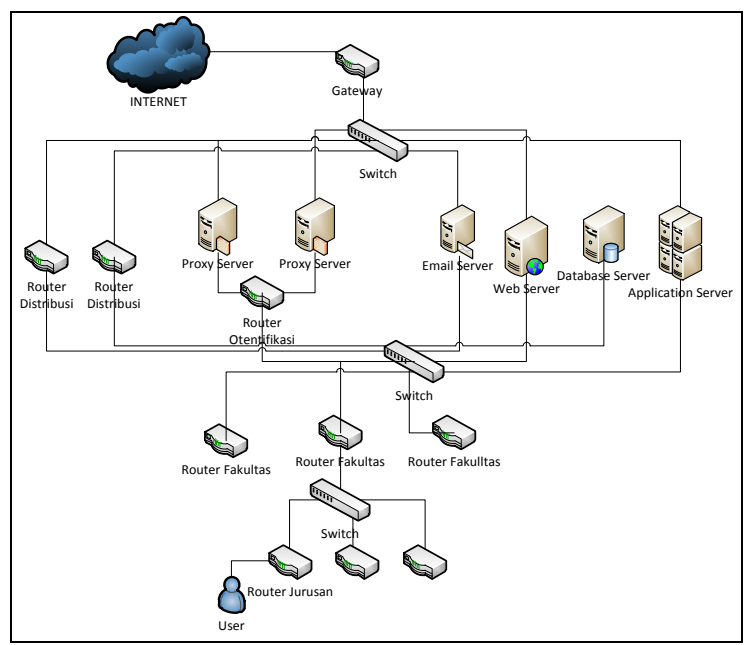

Gambar 3 Topologi jaringan Unand sebelum $\mathrm{DMZ}$

Kondisi awal jaringan Internet Universitas Andalas memperlihatkan bahwa tidak terdapat sistem yang menghalangi server dan internet. Sehingga Server berhadapan secara langsung dengan internet. Penerapan DMZ akan membatasi serangan dari Internet terhadap server yang ada.

\section{METODOLOGI}

Metodologi yang digunakan pada penelitian ini adalah membangun topologi jaringan Universitas Andalas dengan menempatkan server-server ke dalam sebuah lingkungan DMZ, mengkonfigurasi Router DMZ kemudian menguji dan menganalisa jaringan yang telah dirancang dan diterapkan secara riil.

\section{III.1. Membangun Topologi Jaringan}

Topologi Firewall DMZ UNAND pada penelitian ini adalah sebagaimana diperlihatkan pada gambar 4. Topologi ini menempatkan server-server yang berada di 
jaringan backbone ke dalam jaringan yang berada dibelakang firewall DMZ.

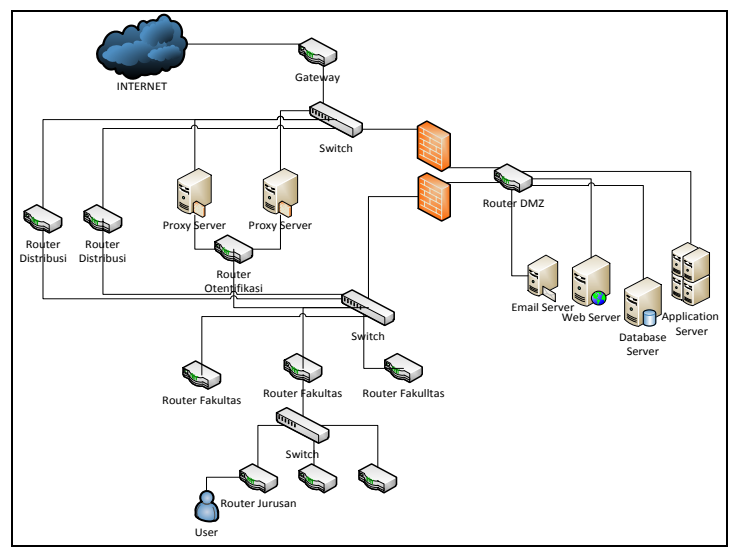

Gambar 4 Topologi jaringan Unand setelah DMZ

\section{III.2. Konfigurasi Router sebagai DMZ}

Protokol Routing yang digunakan adalah OSPF (Open Shortest Path First). Protokol Routing ini sudah digunakan diseluruh backbone Universitas Andalas sehingga routing bisa lebih cepat dan mudah dikonfigurasi karena bersifat dinamis. Pengaturan Firewall DMZ di setting pada router dengan memanfaatkan skenario NAT (Network Address Translation) dan PAT (Port Address Transation).

\section{III.3. Pengujian dan Analisa}

Untuk melihat perbandingan layanan menggunakan firewall DMZ dengan layanan sebelum menggunakan DMZ, maka dilakukan pengujian dengan menjalankan perintah ping dari user ke alamat server. Perintah ini akan menghasilkan nilai round-trip time (RTT). Round-trip delay adalah waktu yang dibutuhkan paket dari sumber ke tujuan dan kembali lagi ke sumber.

Percobaan yang dilakukan adalah sebanyak 10 kali pada saat tidak menggunakan DMZ dan 10 kali saat menggunakan DMZ. Masing-masing perintah melakukan perulangan sebanyak 50 kali.

\section{HASIL DAN PEMBAHASAN}

Tabel 1 memperlihatkan hasil RTT yang didapatkan pada saat pengujian dengan menggunakan DMZ dan tidak menggunakan
DMZ. Pengujian dilakukan antara jam 18:00 hingga 20:00. Pada saat itu jaringan internet secara real tidak mengalami kesibukan traffik.

Tabel 1: RTT hasil Pengujian pada jam tidak sibuk

\begin{tabular}{|c|c|c|c|c|c|c|}
\hline \multirow{2}{*}{ Uji } & \multicolumn{3}{|c|}{ Tanpa DMZ } & \multicolumn{3}{c|}{ DMZ } \\
\cline { 2 - 7 } & $\begin{array}{c}\text { min } \\
(\mathrm{ms})\end{array}$ & $\begin{array}{c}\text { avg } \\
(\mathrm{ms})\end{array}$ & $\begin{array}{c}\text { max } \\
(\mathrm{ms})\end{array}$ & $\begin{array}{c}\text { min } \\
(\mathrm{ms})\end{array}$ & $\begin{array}{c}\text { avg } \\
(\mathrm{ms})\end{array}$ & $\begin{array}{c}\max \\
(\mathrm{ms})\end{array}$ \\
\hline 1 & 0,114 & 0,267 & 1,892 & 0,205 & 0,408 & 3,748 \\
\hline 2 & 0,115 & 0,395 & 2,371 & 0,303 & 0,414 & 1,619 \\
\hline 3 & 0,114 & 0,303 & 1,011 & 0,236 & 0,33 & 0,461 \\
\hline 4 & 0,112 & 0,281 & 1,646 & 0,284 & 0,355 & 0,455 \\
\hline 5 & 0,114 & 0,282 & 0,989 & 0,298 & 0,348 & 0,474 \\
\hline 6 & 0,118 & 0,526 & 4,933 & 0,292 & 0,498 & 3,773 \\
\hline 7 & 0,114 & 0,23 & 0,785 & 0,296 & 0,363 & 0,741 \\
\hline 8 & 0,172 & 0,457 & 4,382 & 0,283 & 0,37 & 0,452 \\
\hline 9 & 0,138 & 0,436 & 2,097 & 0,306 & 0,365 & 0,992 \\
\hline 10 & 0,113 & 0,251 & 1,087 & 0,265 & 0,431 & 3,77 \\
\hline
\end{tabular}

Dari tabel 1 terlihat bahwa terjadi kenaikan delay waktu saat DMZ diterapkan. Kenaikan pada saat nilai minimal terlihat lebih teratur dibanding saat nilai maksimal dan nilai rata-rata diambil. Hal ini terjadi karena pada saat pengujian dilakukan, terjadi fluktuasi kesibukan jaringan yang berbeda-beda. Pada saat tertentu tiba-tiba terjadi delay yang sangat besar pada nilai maksimalnya. Pengaruh lain adalah disebabkan routing jaringan yang menjadi penentu arah perjalanan paket.

Untuk memudahkan dalam melihat perbandingan saat diterapkan DMZ dan saat tidak diterapkan DMZ, maka dibuat sebuah grafik nilai minimal (dalam mili detik) sebagaimana gambar 4 .

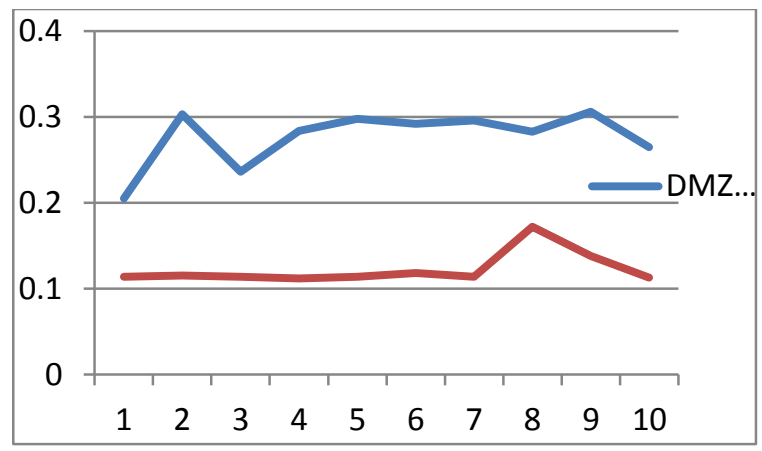


Gambar 5 Grafik perbandingan saat diterapkan DMZ dan saat tidak diterapkan pada jam tidak sibuk ( pukul $18.00-20.00$ ).

Rata-rata delay pengiriman paket minimum tanpa DMZ adalah 0,1224 ms sedangkan saat diterapkan DMZ sebesar 0,2768 ms. Sehingga didapatkan penurunan kecepatan paket setelah diterapkan DMZ sebesar 0,1544 ms atau setara dengan $126 \%$. Penurunan ini disebabkan oleh penambahan router di sisi network server. Sehingga terjadi delay pada masing-masing perangkat dan delay pada network.

Tabel 2: RTT hasil Pengujian pada jam sibuk

\begin{tabular}{|r|c|r|r|r|r|r|}
\hline \multirow{2}{*}{ Uji } & \multicolumn{3}{|c|}{ Tanpa DMZ } & \multicolumn{3}{c|}{ DMZ } \\
\cline { 2 - 7 } & Min & Avg & maks & Min & Avg & maks \\
\hline 1 & 0,114 & 0,213 & 1,169 & 0,27 & 0,32 & 0,421 \\
\hline 2 & 0,114 & 0,407 & 1,673 & 0,225 & 0,364 & 2,456 \\
\hline 3 & 0,114 & 0,25 & 1,22 & 0,264 & 0,362 & 1,159 \\
\hline 4 & 0,109 & 0,257 & 1,596 & 0,218 & 0,315 & 0,556 \\
\hline 5 & 0,108 & 0,282 & 1,005 & 0,218 & 0,377 & 2,461 \\
\hline 6 & 0,114 & 0,28 & 1,262 & 0,24 & 0,377 & 2,043 \\
\hline 7 & 0,113 & 0,377 & 1,77 & 0,278 & 0,411 & 3,895 \\
\hline 8 & 0,116 & 0,274 & 1,447 & 0,279 & 0,333 & 0,426 \\
\hline 9 & 0,111 & 0,392 & 4,719 & 0,267 & 0,372 & 1,401 \\
\hline 10 & 0,109 & 0,318 & 3,585 & 0,292 & 0,343 & 0,437 \\
\hline
\end{tabular}

Berdasarkan tabel 2, maka dibuat grafik sebagaimana yang diperlihatkan pada gambar 6.

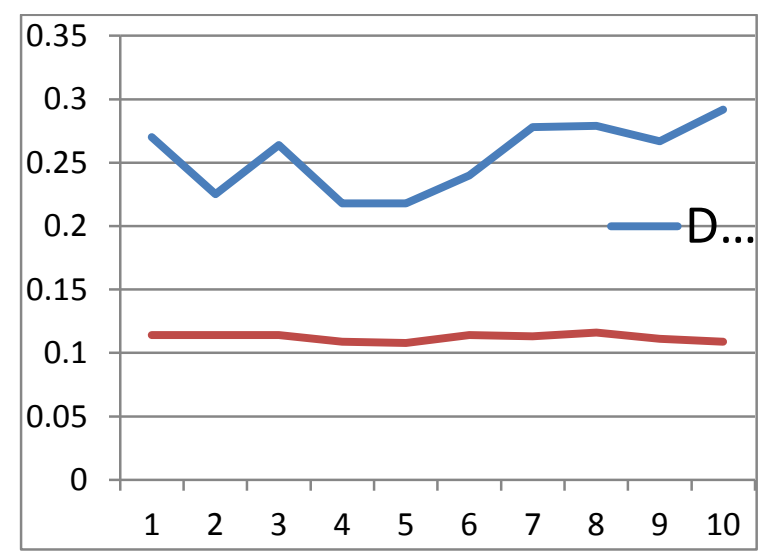

Gambar 6 Grafik perbandingan saat diterapkan DMZ dan saat tidak diterapkan pada jam sibuk (pukul $11.00-14.00$ ).

Rata-rata delay pengiriman pada saat diterapkan DMZ adalah sebesar 0,2551 ms sedangkan saat belum diterapkan DMZ adalah sebesar 0,1122 ms. Sehingga didapatkan penurunan kecepatan paket setelah diterapkan DMZ sebesar 0,1429 ms. Penurunan kecepatan ini berarti bahwa pada penerapan firewall DMZ, terjadi kenaikan delay sebesar $127 \%$ pada jaringan Universitas Andalas yang menuju pada server.

Berdasarkan data diatas, maka diketahui bahwa pada saat jam sibuk dan pada saat tidak sibuk terdapat penurunan kecepatan penghantaran paket data sebesar 126\% hingga $127 \%$. Kenaikan delay diakibatkan oleh beberapa faktor, diantaranya adalah delay propagasi dan delay proses pada router DMZ.

\section{KESIMPULAN}

Adapun kesimpulan yang dapat ditarik dari penelitian ini adalah bahwa rata-rata delay pengiriman paket minimum tanpa DMZ dan saat diterapkan DMZ mengalami kenaikan sebesar $126 \%$ hingga $127 \%$. Hal ini disebabkan karena penambahan router firewall pada sisi antara jaringan luar (publik dan lokal) terhadap server. Penambahan router ini menjadikan penambahan waktu pada saat melewati router terutama saat membuka paket dan menyalurkannya sesuai kebijakan firewall.

\section{DAFTAR PUSTAKA}

[1] Will Schmid, Victor Cang, Robert J Shimonski, dkk, "Building DMZs for Enterprise Networks", United States of America, 2003

[2] Brij Bhooshan, Ramesh Chand Joshi, and Manoj Misra, "ANN Based Scheme to Predict Number of Zombies in a DDos Attack", International Journal of Computer Science and Network Security, Vol.14, No.2, pp61-70,Maret 2012

[3] I-Wei Chen, Po-Ching Lin, dkk, "Extracting Ambiguous Sessions from Real Traffic with Intrusion Prevention Systems", International Journal of Computer Science and Network Security, Vol.14, No.5, pp243-250, Sept 2012

[4] Miaomiao Tian, Wei Yang, and Liusheng Huang, "Security of a Biometric Identitybased Encryption Scheme", International Journal of Computer Science and 
Network Security, Vol.14, No.6, pp362365, Nov 2012

[5] Kashif Munir and Sellapan Palaniappan, "Security Threats/Attcks Present in Cloud Environment", International Journal of Computer Science and Network Security, Vol.12 No.12, December 2012

[6] Hesham Abusaimeh and Mohammad Shkoukani,"Survey of Web Application and Internet Security Threats", International Journal of Computer Science and Network Security, Vol.12 No.12, December 2012

[7] Mehdi Jahanirad, Yahya Al-Nabhani, Rafidah Md.Noor,"Comprehensive Network Security Approach: Security Breaches at Retail company- A Case Study", International Journal of Computer Science and Network Security, Vol.12 No.8, August 2012

[8] N. Ahmed, Z.I.A. Khalib, R.B. Ahmad, Suhizaz Sudin, Salina Asi, Yacine Laalaoui,"Low-End Embedded Linux Platform for Network Security Application - Smurf Based Attack Detection", International Journal of Computer Science and Network Security, Vol.8 No.11, November 2008

[9] Nguyen Hieu Minh, Do Thi Bac and Ho Ngoc Duy,"New SDDO-Based Block Cipher for Wireless Sensor Network Security", International Journal of Computer Science and Network Security, Vol.10 No.3, March 2010

[10] Ramy K. Khalil, Fayez W. Zaki , Mohamed M. Ashour, and Mohamed A. Mohamed,"A Study of Network Security Systems", International Journal of Computer Science and Network Security, Vol.10 No.6, June 2010

[11] Michael Rash,"Linux Firewall : attack detection and response with iptables, psad, and fwsnort",San Fransisco,2007

[12] Ammar Yassir and Smitha Nayak,"Cybercrime: A threat to Network Security", International Journal of Computer Science and Network Security, Vol.12 No.2, June 2012

[13] Syedur Rahman, A.M Ahsan Feroz, Md. Kamruzzaman and $\mathrm{Md}$ Azimuddin Khan,"Online Identity Theft and Its Prevention Using Threshold Cryptography", International Journal of
Computer Science and Network Security, Vol.10 No.9, June 2010

[14] http://www.snort.org/ diakses tanggal 7 Januari 2012. Jam 9.04 wib

[15] http://www.tenable.com/products/nessus diakses tanggal 7 Januari 2012. Jam 9.05 wib

[16] Addy Suyatno,"Aplikasi Model Sistem Keamanan Jaringan Berbasis DeMilitarised Zone", Volume 4 No. 1 Februari 2009

[17] http://www.unand.ac.id/index.php/id/profi 1/sejarah diakses tanggal 23 Januari 2014.

[18] Sardana, A, Joshi, RC,"Autonomous Dynamic Honeypot Routing Mechanism for Mitigating DDoS Attacks in DMZ",16th IEEE International Conference on ,New Delhi,2008

[19] https://www.iwebgate.com/service_dmz.h tml diakses tanggal 23 Januari $20 \overline{14}$. Jam $12.12 \mathrm{Wib}$.

[20] http://www.mikrotik.co.id diakses pada 23 Januari 2014 jam $21.52 \mathrm{Wib}$

[21] Glen Nakamoto, Jeff Schwefler and Kenneth Palmer. " Desktop Demilitarized Zone", Military Communications Conference, 2012 - Milcom 2012, On page(s): 1487 - 1492

[22] Sardana, A, Joshi, RC,"Autonomous Dynamic Honeypot Routing Mechanism for Mitigating DDoS Attacks in DMZ",16th IEEE International Conference on ,New Delhi,2008

\section{Biodata Penulis}

Syariful Ikhwan, dilahirkan di Air Bangis Sumatera Barat tanggal 5 April 1982. Pendidikan SD hingga pertengahan kelas 3 dilalui di kampung kelahiran Ayah, Ujung Gading. Kelas 3 SD hingga tamat dan dilanjutkan dengan sekolah SMP dilalui di kampung ibunda tercinta yakni di Air Bangis. Setelah tamat SMP memperoleh kemudahan untuk sekolah di kelas khusus SMA Negeri 1 Lubuk Sikaping. Tamat SMA kemudian melanjutkan pendidikan di Teknik Elektro Universitas Andalas Padang dan meraih gelar Sarjana Teknik pada tahun 2008. Aktifitas saat ini sebagai staff jaringan di Lembaga Pengembangan Teknologi Informasi dan Komputer (LPTIK) Universitas Andalas. 